\title{
Commentary
}

\section{Establishment and Development of the Post-war New International Civil and Commercial Order*}

\author{
Huang Jin \\ Rector \& Professor of Law, China University of Political Science and Law, \\ Beijing; President, China Society of Private International Law; \\ Vice President, China Law Society; Vice President, Chinese Society \\ of International Law \\ huangjin@cupl.edu.cn
}

\begin{abstract}
Supported by new rules of private international law, a new international civil and commercial order has taken shape, comprising international civil and commercial jurisdiction rules, conflict-of-law rules, international civil and commercial judicial assistance rules and disputes resolution mechanism. Different from the international economic order, the new international civil and commercial order stands side by side and complements the new international economic order, as well as the new international political order. As the international civil and commercial order continues developing in an open, inclusive, multilateral, and flexible way, it will play a more important role in safeguarding international security and prosperity, and promoting common interests of humankind. In this context, safeguarding, improving, and actively promoting the international civil and commercial order is of vital significance for China's peaceful rise and the realization of China's dream of great rejuvenation.
\end{abstract}

* I would like to thank Prof. HUO Zhengxin and Mr. LU Yong for their assistance on this paper. 


\section{Keywords}

New international civil and commercial order - New international economic order Rules of private international law - China's peaceful rise

\section{Introduction}

Learning from the painful lessons of the two world wars in the last century, the international community has come to realize the great necessity of maintaining peace, strengthening collaboration, promoting development, protecting human rights, and establishing a sound new international order through joint efforts. Since the end of the World War II, the international community has made great achievement in striding toward a new international order by fundamentally reforming the weak and unreasonable existing international framework. The new international order has now taken shape after 70 years' development, which takes peace, collaboration, development, and human rights as its core idea, rules building as its key mission, maintaining and promoting international political security, economic development, human rights and people's livelihood as its main targets. The new international order, completely different from the old one, consists of the following three key elements: "new international political order", "new international economic order", and "new international civil and commercial order". From a legal perspective, they are supported and maintained by public international law, international economic law, and private international law respectively.

Considering that the new international political order and new international economic order have gained wide attention, here I will focus my topic on the establishment and development of post-war new international civil and commercial order, illuminating its structure and function, and analyzing its difference vis-à-vis the new international economic order. In then end, I would predict its development trend of the new international civil and commercial order, and the position China should take therein.

2

\section{Establishment and Structure of the New International Civil and Commercial Order}

Current international exchanges value equality and mutual benefit. In a globalized world, such a kind of equality and mutual benefit features in a 
"dual-tier structure" which requires equality and mutual benefit not only between countries but also between natural persons and legal persons across the different countries. In nature, the two tiers are different from each other, as the former falls within public law, while the latter private law. However, functionally the two tiers are inextricable intertwined. Obviously, equality and mutual benefit between countries is the precondition for that between natural persons or legal persons. From another angle, equality and mutual benefit between countries is just like a castle in the air which would not survive if natural persons and legal persons in different countries cannot be equally treated and their rights and interests cannot be equally guaranteed.

What's more, the post-war international community has built a new international political order backed by new rules of public international law through founding the United Nations, stipulating the UN Charter, and improving international law, etc. By reforming the international monetary, financial and trade systems and establishing the World Bank, the International Monetary Fund and the World Trade Organization, the international community has established a new international economic order bolstered by new rules of international economic law. Based on the two new orders, peace, mutual benefits and development among countries are ensured.

Meanwhile, upholding the banner of justice, equality, freedom, inclusiveness and efficiency, the international community has abolished the old civil and commercial systems, and established a new international civil and commercial order supported by new rules of private international law. To be more specific, the new rules include international civil and commercial jurisdiction rules, conflict-of-law rules, international civil and commercial judicial assistance rules and disputes resolution mechanism. In such, equality and win-win cooperation in the international exchanges of natural persons and legal persons have been guaranteed, and new rules of private international law has finally become the ballast for world peace and development. The whole process has been accomplished by the joint effort of countries in the world, inter-governmental organizations including the Hague Conference on Private International Law, the International Institute for the Unification of Private Laws, the United Nations Commission on International Trade Law, regional organizations such as the Asian-African Legal Consultative Committee, the European Union, the Organization of American States, and non-governmental organizations like the International Chamber of Commerce. As an important component of new international order, the new international civil and commercial order exists side by side and complements the new international political and economic orders. 


\section{Difference between the New International Civil and Commercial Order, and the New International Economic Order}

The new international civil and commercial order and new international economic order are closely connected to each other, and overlap in some areas. However, it should be pointed out that they are different in many aspects, such as nature, scope and function which should not be mixed up.

In terms of nature, the new international civil and commercial order is built on the rules adjusting cross border civil and commercial exchanges between private parties (including natural persons and legal persons) from different countries, while the new international economic order on those adjusting economic relations between sovereign states. In terms of normative system, the former includes, on an equal and voluntary basis, systems such as international contracts, international torts, international marriage and family, international commercial transaction and applicable law for international civil and commercial affairs. Moreover, it includes systems that aim at promoting international civil and commercial relations such as international civil and commercial jurisdiction, legal assistance, disputes resolution mechanism. The latter, however, refers to systems based on international division of labor and international assistance, including international regulations concerning trade, finance and currency, taxation and investment. In terms of function, the establishment of new international civil and commercial order targets at coordinating civil and commercial conflicts between countries by relying on domestic legislative and judicial organs of each country. By doing so, it ensures stability and prosperity of international civil and commercial relations. On the other hand, the establishment of new international economic order is designed to adjust different political and economic systems of countries. It ensures economic security and sustainable development of countries with the aid of international organizations.

After the seventy years' development since the end of World War II, the international civil and commercial legal system has realized a "Copernican revolution" in terms of its ideology and regulatory system and a brand new international civil and commercial order has taken shape via the joint effort of international community, which plays an irreplaceable role for international civil and commercial exchanges, as well as the world peace and prosperity.

Different from the core idea of the old order which adhered to the absolute self-interest blindly, the new international civil and commercial order aims at maintaining common international interests. It has abolished the elements contained in the old order such as self-reclusiveness, unilateralism and rigidness. Furthermore, it puts citizens and aliens, lex fori and foreign law, on 
the equal footing, establishes new rules characterized as openness, inclusiveness, multilateralism, and flexibility. Thus, international civil and commercial exchanges have been safeguarded and the whole and long-term interests of the international community have been protected at the new and institutional level.

From the angle of regulatory system, a new international civil and commercial regulatory system has taken shape which has been playing a more and more important role in international legal systems under joint coordination of authoritative inter-governmental organizations such as the United Nations, the Hague Conference on Private International Law, and the International Institute for the Unification of Private Laws. The new system is composed of a complex set of rules in which international uniform substantive rules and conflicts rules are the core, while the rules on the status of foreigners, international civil procedure law as well as international commercial arbitration are the peripheral areas.

Thus, the new international civil and commercial order is an inevitable outcome of international community's demand in abolishing the old order in a globalized world. It will, together with the new international political and economic orders, safeguard the new order of the post-war world.

\section{$4 \quad$ New International Civil and Commercial Order Facing the 21st Century and China's Position}

The world today has entered its second decade in the 21st Century and will soon celebrate the 7oth anniversary of the victory of the World War II. Under the new historical conditions, the international landscape is continuing to undergo deep changes. Among all those changes, the most notable ones are the strengthening of a community of human destination, and uprising of emerging countries with China as a representative. In this light, how the international civil and commercial order will develop and what position China should take under the new historical circumstance, in my opinion, are topics worthy of attention and discussion.

Considering that the community of human destination has emerged and consolidated, I believe that the international civil and commercial order will continue to develop in an open, inclusive, multilateral and flexible way which will play a more important role in safeguarding international security and prosperity, and promoting common interests of humankind.

In comparison with the international political order and international economic order, the international civil and commercial order features in a 
following way: in nature, it is both private and transnational; in mechanical function, it depends on both, national efforts and international coordination, in other words, it is dependent on national legislative and judicial organs as well as international coordination. Consequently, in face of international new challenges, the international civil and commercial order is most tenacious and flexible, and is capable of making self-adjustment and improvement adaptable to the new circumstances. Therefore, the significance and the merits of international civil and commercial order will be more conspicuous in the 21st century.

As far as China is concerned, I think that safeguarding, improving and actively promoting the international civil and commercial order is of vital significance for China's peaceful rise and the realization of China's dream of great rejuvenation.

First of all, international security, stability and prosperity in the 21st century depends to a large extent whether emerging powers represented by China can avoid falling into Thucydides's trap with and the established powers represented by the Us, in which, the international civil and commercial order plays a crucial role. As the ancient Chinese saying goes, "Amity between people holds the key to sound relations between states", provided that the civil and commercial exchanges between countries become more frequent and smooth, the disputes will be addressed in a fairer, more reasonable and convenient way, an equal and win-win collaboration between countries would be guaranteed. For this reason, I compared the new international civil and commercial order to the ballast for a sustained international peace and prosperity in the very beginning of my speech.

Secondly, the new international civil and commercial order is the most reliable and convenient means to peacefully solve some international disputes because it mainly counts on national judicial or quasi-judicial organs' rulings and judgments under applicable civil and commercial law, or shortly, the applicable law which hardly touchs the sensitive issues, such as sovereignty, politics and security. For example, historical issues, in particular the responsibility of Japan's aggression against China, are burdens that have bothered China and Japan for a long period. However, a recent case, "Zhongwei Case", in China shows that civil judgment can avoid those sensitive issues and solve the disputes effectively. In 2014, the Shanghai Maritime Court of China detained, in line with China's Civil Procedure Law and Special Maritime Procedure Law, a vessel owned by the Japanese Mitsui Company to urge it to perform the judgment rendered by a China's court. In such, it drew a sound end to the 26-year long "Zhongwei Case". Because the court ruling safeguards the authority of Chinese law and justice, and shapes a good image of rule of 
law in China, it has received positive response from the international legal community. In the context of the difficult China-Japan relation, a sound solution of a long and complex transnational dispute by a court's civil ruling is enough to show the advantage and special value of civil and commercial order in solving transnational disputes.

Therefore, China should strive to rebuild the new international civil and commercial order in creating a favorable ensuring mechanism for China's peaceful rise in the future. It's worth mentioning that China is actively advancing the strategy of the "Silk Road Economic Belt" and the "21st Century Maritime Silk Road", "one belt, one road" strategy in short, which aims at establishing a community that shares interests, fortune and responsibility, and features in a political mutual trust, economic integration and cultural inclusive way. In this process, actively using, improving and developing new international civil and commercial order, undoubtedly, will play a special role as a booster and pressure reducing valve for the strategy.

\section{$5 \quad$ Conclusion}

In conclusion, the new international civil and commercial order established after the end of the World War II is of great significance for both China and the world at large. In particular, the new order, due to its unique characteristics, will play a more significant role in enhancing a lasting peace, prosperity, development and people's well-being for China and the whole world in the 21st century while China rises rapidly, on which I have a full confidence. 